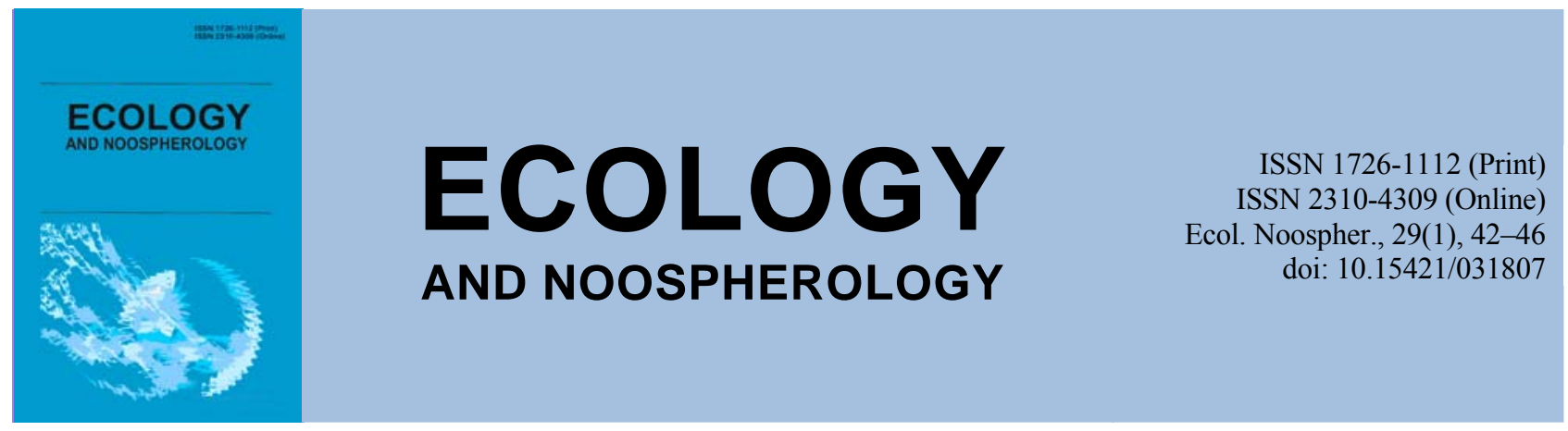

\title{
Scientific aspects of supplying the population with transported water
}

\author{
O. V. Zorina
}

State Institution «O. M. Marzeiev Institute for Public Health, NAMSU», Kyiv, Ukraine

Article info

Received 17.05.2018

Received in revised form

29.05.2018

Accepted 05.06.2018

State Institution «O. M. Marzeiev Institute for Public Health, NAMSU»,

Popudrenko St., 50, Kyiv, 02094, Ukraine.

Tel.: +38-050-932-36-50

E-mail: wateramnu@ukr.net
Zorina, O. V. (2018). Scientific aspects of supplying the population with transported water. Ecology and Noospherology, 29(1), 42-46. doi:10.15421/031807

The research was conducted with the purpose of giving the scientific evaluation of the prevalence of supplying the population with transported potable water, its quality, and reveals the problems of regulatory framework in this sphere with the aim to improve the legislation and develop preventive measures for prevention of morbidity of the population. In this research were used following methods: hygienic, chemical, standard searching, and method of expert evaluation. It was determined that according to the data for the 2016, 10 regions of Ukraine are supplied with transported water in tanker due to the absence or deficit of the water of potable quality ( 8 regions - on the south and south-east, 2 regions - on the west of Ukraine). In order of increasing of the number of human settlements, which are supplied with the transported potable water, mentioned regions can be put in the following row: Zaporizka $>$ Dnipropetrovska $>$ Mykolaivska $>$ Odeska $>$ Donetska $>$ Lvivska $>$ Kyrovogradska $>$ Khersonska $>$ Poltavska $>$ Ivano-Frankivska. Herewith, in order of increasing of the number of population supplied with the transported water can be put in the following row: Mykolaivska $>$ Kyrovogradska $>$ Zaporizka $>$ Odeska $>$ Dnipropetrovska $>$ Khersonska $>$ Donetska $>$ Lvivska $>$ Poltavska $>$ Ivano-Frankivska. Dynamics analysis of potable transported water availability in human settlements of selected regions of Ukraine found that transported potable water intended for drinking in 2009 was used in 11 regions, in 2014 has not been used in Vinnitska and Poltavska region, however, the transportation of potable water started in 2014-2016 in Lvivska region. Were identified problematic regions, where was observed an increase in supply of transported water in recent years: Zaporizka $>$ Dnipropetrovska $>$ Mykolaivska $>$ Odeska $>$ Donetska $>$ Lvivska $>$ Kyrovogradska. It has been established that as for today the quality of transported water is not controlled by the State supervisory authorities. The need of reglamentation of the quality and recommendations on the quantity of transported potable water in emergencies in SanPiN, what is topical issue for Ukraine, was identified. According to the requirements of European legislation the quality of such water must meet the standard for potable tap water (Directive 98/83/EU on water intended for human consumption). According to the data from scientific literature and personal research the minimum quantity of such water per capita in emergencies should be 10 liters a day ( 5 litres - for hygienic needs and 5 liters - for internal use). However, it is should be taken into account that the regime of limitation of water consumption in considerable heat and/or physical activity conditions should not be applied. Moreover, population should be supplied with enough quantity of potable water for all physiological needs of organism when opportunities are presented. The alternative to transported potable water under appropriate conditions is a usage of mobile points of water purification and bottling of potable water installed in automobile transport, which also have an advantage of possibility to supply the consumers with the potable water in unlimited quantities over an extended period of time. Our classification of transported water was implemented in SanPiN 2.2.4-171-10 and project of new edition of this document. SanPiN 2.2.4-171-10 regulate the requirements to the potable water of improved quality, which is bottled for commercial purpose in personal packaging of consumers from the mobile bottling points (tankers) or is transported to consumer in refillable packaging (packed tare). Quality of transported potable waters, which are usually bottled for commercial purpose, and must have an improved quality, was analyzed. Only $31 \%$ among the 129 analyzed packaged potable waters and waters from boiling points were produced for sale from boiling points or in refillable packaging. Quality of 74 from 129 analyzed waters didn't meet the requirements after the installation of equipment or long-term production. 12 problematic indicators were found in waters after additional treatment of tap potable waters ( 8 - from surface sources) and 13 - in underground 
sources. The most frequently detected substance in groundwater was silicon in concentration up to $3,8 \mathrm{MAC}$ ( $47 \%$ of samples) or dry residue in concentration $<100 \mathrm{ml} / 1$ ( $24 \%$ of samples), and in additionally treated tap water - chloroform in concentration up to $18 \mathrm{MAC}(51 \%$ of samples, $\mathrm{MAC}-6 \mu \mathrm{g} / \mathrm{l})$, and/or dry residue in concentration $<100 \mathrm{mg} / \mathrm{l}$ (36\% of samples). It was confirmed that the schemes of water treatment for potable water from bottling points in personal tare of consumer and packed water are developed without taking into account the type, quality of source water, and the efficiency of water treatment methods. Scientific novelty of obtained results lies in determination of regularities in supply of the transported potable water in Ukraine at special and temporal scale. It was the first time when the classification of transported waters depending on the quality of potable water and type of tare for transportation to the consumer was developed. Practical value of this research is that it is possible to determine the regions in Ukraine with the potable water shortage, which are transported not with the commercial purpose, and also that several provisions of SanPiN 2.2.4-171-10 «Hygienic requirements to the potable water intended for human consumption» (and their new edition were developed with the objective of implementing of the Directive 98/83/EU on water, intended for human consumption.

Keywords: transported potable water; bottling points; human settlements

\title{
Наукові аспекти забезпечення населення привізними питними водами
}

\author{
О. В. Зоріна \\ ДУ «Інститут громадського здоров'я ім. О. М. Марзєєва НАМНУ», Київ, Украӥна
}

Виявлено, що за даними 2016 р. в Україні деякі регіони 10 областей забезпечуються привізною питною водою. За останні роки у 7 областях спостерігається збільшення постачання привізної води. Установлено необхідність регламентації в ДСанПіН 2.2.4-171-10 якості привізних вод, що доставляються не з комерційною метою. Виявлено проблемні показники у привізних питних водах поліпшеної якості після додаткової обробки водопровідних питних вод та з підземних джерел.

Ключові слова: привізна питна вода; пункти розливу; населені пункти

\section{Вступ}

Поміж країн Європи Україна одна із найменш забезпечених водними ресурсами. На півдні та південному сході України спостерігається найбільший дефіцит запасів якісних питних вод (Bardov et al., 2013; Averyn et al., 2002). Дуже часто підземні горизонти відсутні або не мають надійного захисту та забруднені через природні або антропогенні чинники (Fagurova, 2010). Не одне десятиліття в деяких населених пунктах України було дозволено постачати населенню підземну водопровідну питну воду, якість якої не відповідала гігієнічним вимогам за вмістом мінеральних речовин (Prokopov, 2016). На сьогодні видача відповідних дозволів призупинена, але постачання населенню некондиційних водопровідних питних вод продовжується. У населених пунктах, де якість питних вод не відповідає вимогам законодавства, здійснюється постачання питної води в автоцистернах.

У деяких областях існують проблеми 3 кількістю та/або якістю привізних вод. В окремих регіонах виникають проблеми 3 якістю привізної води через техногенні чинники: утворення депресійних воронок у зоні крупних водозаборів підземних вод (Рівненська та Львівська області); забруднення підземних вод нафтопродуктами та іншими шкідливими речовинами (Київська область, Білоцерківський район) тощо. У західних областях України під час повеней і паводків відбувається забруднення місцевих джерел водопостачання, що унеможливлює їх використання без відповідної очистки (Stashuk et al., 2010).

У разі надзвичайних ситуацій $€$ кілька варіантів постачання питної води, до них відносяться: постачання питної води з іншої водопровідної мережі, фасованої питної води, привізної в автотранспорті або очищення питної води на місці ії споживання (U.S. Environmental Protection Agency (EPA), 2011). Забезпечення населення в достатній кількості доброякісною питною водою дозволяє вирішити три основні проблеми:
- попередити вплив води як фактора передачі та наступного виникнення інфекційних захворювань бактеріальної, вірусної та гельмінтної етіології;

- попередити етіологічну роль води у виникненні захворювань, пов'язаних 3 надмірним надходженням в організм речовин $з$ токсичною, алергенною, мутагенною, канцерогенною та ембріотоксичною дією;

- виключити роль води у виникненні у людини нервовопсихічних перевантажень, пов'язаних 3 iї незадовільними органолептичними властивостями як природного, так i штучного походження (Huzhnyak et al., 2011).

Якість води джерел водопостачання та питної відноситься до факторів, що безпосередньо впливають на стан здоров'я населення (Fakhri et al., 2017; Chumak et al., 2016; Smith et al., 2013; Norman et al., 2013., Grazuleviciene et al., 2013).

Отже, на сьогодні є актуальним провести наукову оцінку стану питного водопостачання населення в разі забезпечення привізною водою та нормативного забезпечення цієї сфери.

Мета нашої роботи - провести наукову оцінку поширеності постачання населенню привізних питних вод, їх якості та виявити проблеми нормативного забезпечення цієї сфери 3 метою удосконалення законодавства та розробки профілактичних заходів для запобігання захворюваності населення.

\section{Матеріали та методи}

Було проаналізовано якість питних вод 3 пунктів розливу та фасованих вітчизняного виробництва, що виготовлялися протягом 2013-2017 pp. (129 проб) у різних регіонах України. Досліджували майже 40 санітарно-хімічних показників якості питної води згідно 3 ДСанПіН 2.2.4-171-10 «Гігієнічні вимоги до води питної, призначеної для споживання людиною». Використовувалися стандартизовані методи санітарно- 
хімічного аналізу. Проаналізовано матеріали Національних доповідей про якість питної води та стан питного водопостачання в Україні (Natsionalna dopovid, 2016, 2015, 2014, 2009), вимоги ДСанПіН 2.2.4-171-10 «Гігієнічні вимоги до води питної, призначеної для споживання людиною» та Директиви 98/83/СС щодо води, призначеної для споживання людиною. Методи, що були використані: санітарно-гігієнічні, санітарнохімічні, нормативно-пошуковий та експертної оцінки.

\section{Результати досліджень та їх обговорення}

Згідно $з$ даними Національної доповіді (Chumak et al., 2016) 0,7 \% міст, 12,8 \% селищ міського типу та 29,18 \% сіл України не забезпечені централізованим питним водопостачанням. Основна маса відповідного населення використовує питну воду 3 колодязів (шахтних), каптажів джерел, свердловин (трубчастих колодязів) та/або забезпечується привізною питною водою в автоцистернах (рис. 1).

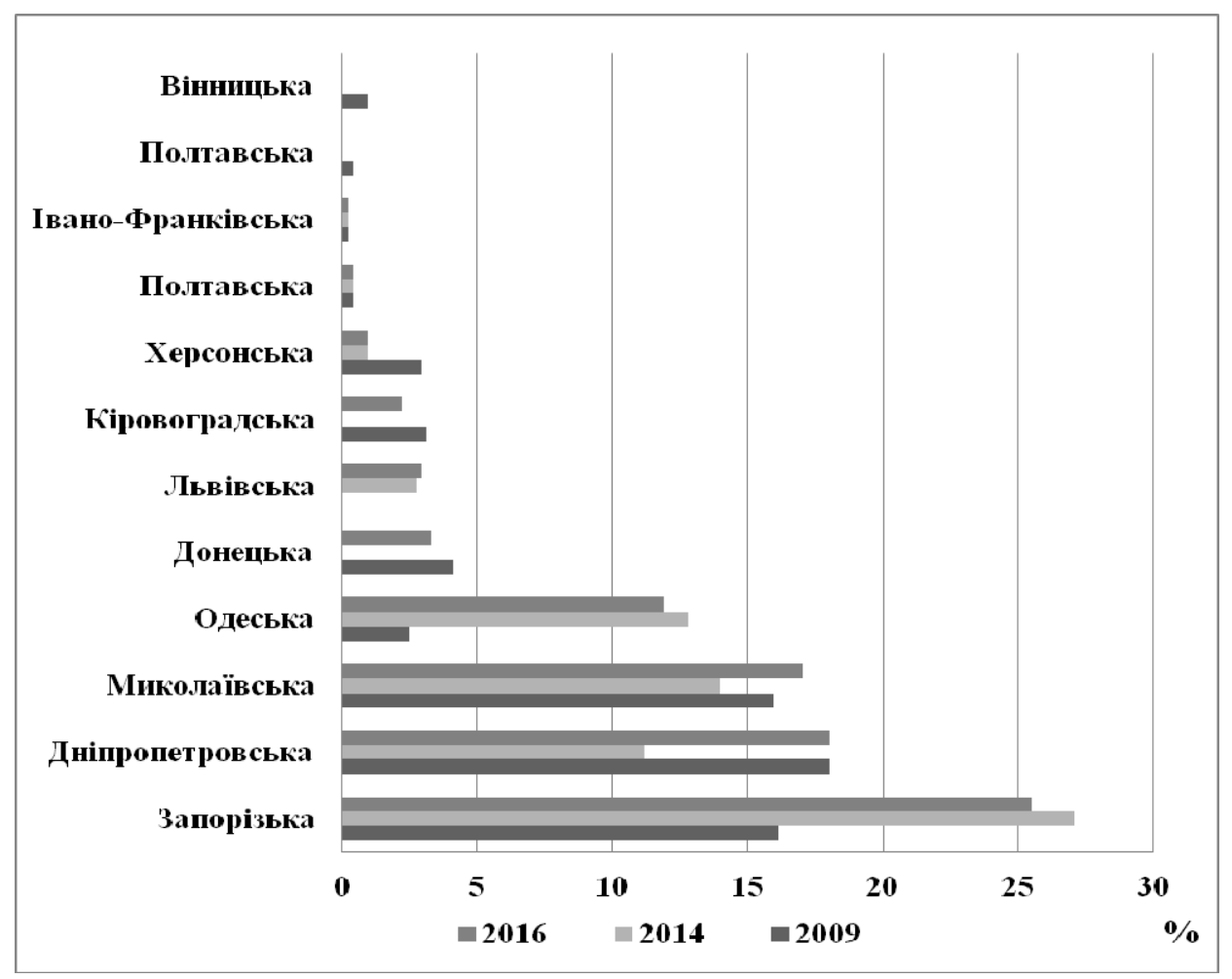

Рис. 1. Забезпеченість населених пунктів окремих областей України привізною питною водою (2016, 2014, 2009 рр.)

За даними 2016 р., населені пункти 10 областей забезпечуються привізною питною водою (8 областей - на півдні та південному сході, 2 області - на заході України). За кількістю населених пунктів, що забезпечуються привізною водою, області країни можна розташувати у такий ряд: Запорізька $>$ Дніпропетровська $>$ Миколаївська $>$ Одеська > Донецька $>$ Львівська $>$ Кіровоградська $>$ Херсонська $>$ Полтавська $>$ Івано-Франківська.

Якщо аналізувати динаміку забезпеченості населених пунктів окремих областей України привізною питною водою, то можна виявити таке. Привізна вода для питних цілей упродовж 2009 року використовувалась в 11 областях, у 2014 р. у Вінницькій та Полтавській областях вже не використовувалася. Однак у 2014-2016 pp. розпочалося постачання привізної питної води у Львівській та суттєво збільшилося в Запорізькій, Одеській областях. У порівнянні з 2014 роком у 2016 році суттєво збільшилося постачання привізної питної води у Дніпропетровській області. Встановлено проблемні області, де за останні роки спостерігається збільшення постачання привізної води: Запорізька > Дніпропетровська $>$ Миколаївська > Одеська > Донецька > Львівська > Кіровоградська.

При цьому за даними 2016 р. за кількістю населення, що забезпечується привізною водою, області можна розташувати в такий ряд: Миколаївська $>$ Кіровоградська $>$ Запорізька $>$ Одеська $>$ Дніпропетровська $>$ Херсонська $>$ Донецька $>$ Львівська $>$ Полтавська $>$ Івано-Франківська. Отже, серед 10 зазначених областей населення Полтавської та Івано-Франківської областей найменше потребують привізної води. У 2016 р. суттєво збільшилася кількість населення, що потребує привізної води, у Миколаївській області (рис. 2).

Виявлено, що на сьогодні якість привізних питних вод державними наглядовими органами не контролюється. Згідно $з$ вимогами європейського законодавства у разі відсутності вільного доступу населення до якісної питної води (після відключення водопроводу тощо) якість привізної води як мінімум повинна відповідати якості питної водопровідної. Однак у ДСанПіН 2.2.4-171-10 «Гігієнічні вимоги до води питної, призначеної для споживання людиною» регламентовано лише вимоги до питної води поліпшеної якості, що розливається 3 комерційною метою в особисту тару споживачів 3 мобільних пунктів розливу (автоцистерн) або доставляється споживачеві у тарі багаторазового використання (у вигляді фасованої) (рис. 1).

За даними наукової літератури (Fagurova, 2010), нашими дослідженнями та відповідно до вимог нормативного документу щодо питного водопостачання Англії мінімальна кількість привізної питної води на одну людину у надзвичайних ситуаціях повинна складати 10 л/добу (5 л - для санітарно-гігієнічних потреб та 5 л внутрішнього споживання), для прання людині може бути необхідно ще біля 10 л. Однак слід ураховувати, що режим обмеження вживання води в умовах значних теплових та/або фізичних навантажень не повинен застосовуватися. Крім того, в усіх випадках, коли створюється можливість, необхідно забезпечувати людей такою кількістю питної води, яка необхідна для покриття всіх фізіологічних потреб організму. При цьому рекомендується пити воду в невеликій кількості (200-250 мл) 3 інтервалом у 15-20 хвилин. 


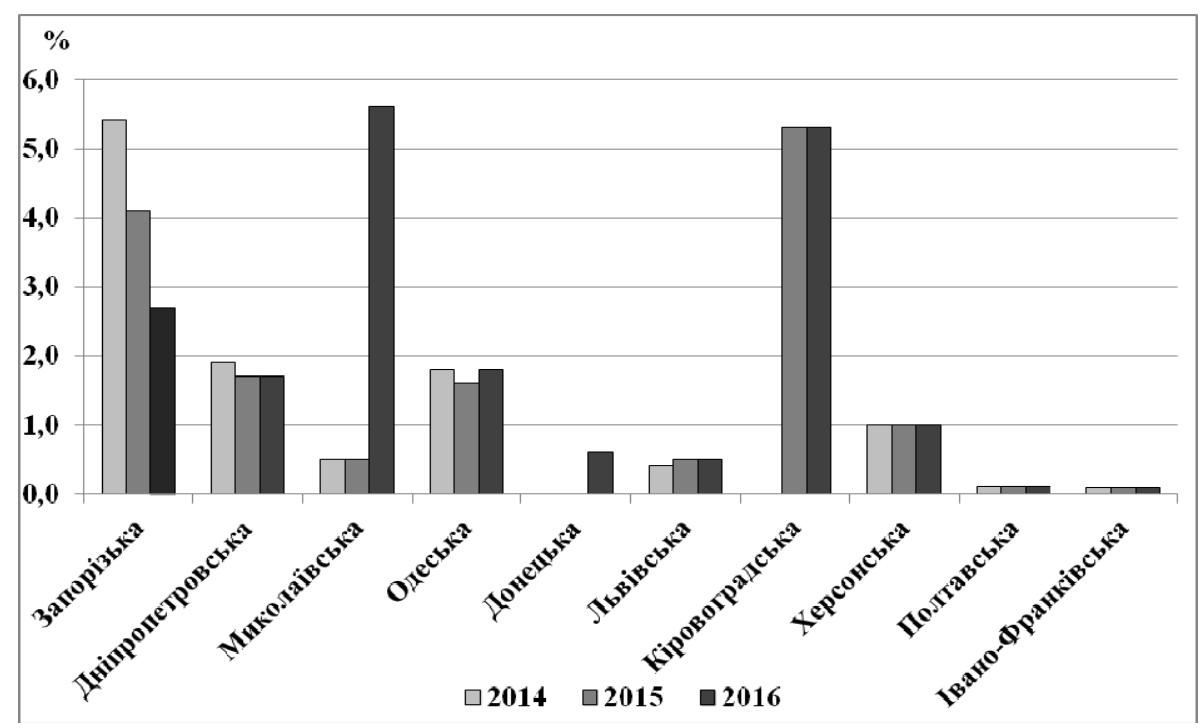

Рис. 2. Забезпеченість населення окремих областей України привізною питною водою

Такий питний режим є найдоцільнішим і обгрунтованим у фізіолого-гігієнічному відношенні (Huzhnyak et al., 2011). У багатьох випадках як альтернативу привізній питній воді слід рекомендувати використання мобільних пунктів очищення та розливу питної води, встановлені в автомобільному транспорті. Однією із переваг $є$ можливість забезпечення питною водою споживачів у необмеженій кількості протягом тривалого часу.

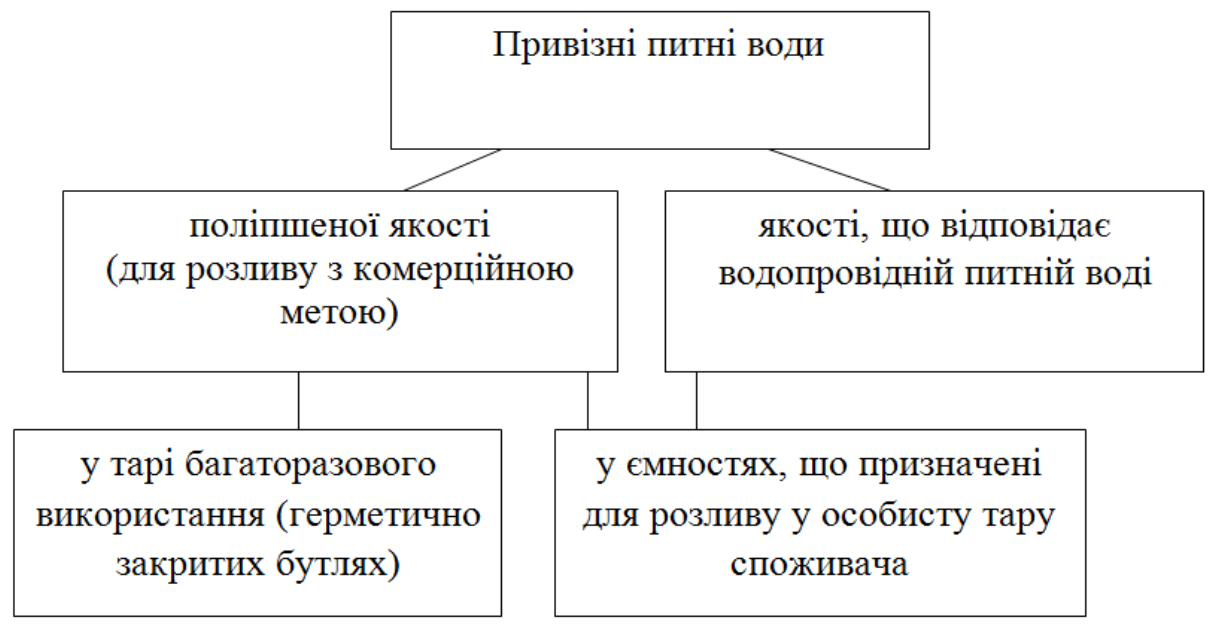

Рис. 3. Класифікація привізних питних вод

Проаналізовано якість привізних питних вод, що розливаються зазвичай з комерційною метою, та повинні мати поліпшену якість згідно з ДСанПіН 2.2.4-171-10. За результатами наших досліджень установлено, що серед досліджених 129 питних вод фасованих та 3 пунктів розливу тільки $31 \%$ виготовлялось насамперед після очищення для реалізації з пунктів розливу або в тарі багаторазового використання (з кодом за ДКПП 36.00.11), інші - одноразового використання (з кодом за ДКПП 11.07). Серед 129 досліджених питних вод 57 \% мали якість, що не відповідала гігієнічним вимогам після безпосереднього встановлення обладнання або його тривалого використання. За частотою відхилення від гігієнічних нормативів показники якості питних вод можна розташувати в такий ряд: хлороформ та інші ТГМ > сухий залишок > перманганатна окиснюваність > забарвленість > амоній та нітрати $>$ феноли $>$ водневий показник, кремній, натрій, хлориди, йод (для питних вод, що виготовляються 3 водопровідних); кремній > сухий залишок > забарвленість $>$ нітрати > лужність, марганець, водневий показник, загальна жорсткість, каламутність > загальне залізо > фтор, перманганатна окиснюваність, нітрити (для питних вод 3 підземних джерел). Серед загальної кількості проб невідповідної якості найчастіше у підземних водах виявлявся кремній у концентрації до 3,8 ГДК (47 \% проб) або сухий залишок у концентрації < 100 мг/л (24 \% проб), a у доочищених водопровідних - хлороформ у концентрації до 18 ГДК (51 \%) та/або сухий залишок у концентрації < 100 мг/л (36 \% проб). Підтверджено, що схеми водопідготовки питних вод 3 пунктів розливу в особисту тару споживача та фасованої розробляються без урахування типу, якості вихідної води та ефективності методів водопідготовки.

\section{Висновки}

1. Виявлено, що за даними 2016 р. деякі населені пункти в 10 областях України забезпечуються привізною питною водою в автоцистернах через відсутність або дефіцит води питної якості. За кількістю населених пунктів, що забезпечуються привізною водою, зазначені області країни можна розташувати в такий ряд: Запорізька $>$ Дніпропетровська $>$ Миколаївська $>$ Одеська $>$ Донецька $>$ Львівська $>$ Кіровоградська $>$ Херсонська $>$ Полтавська $>$ Івано-Франківська. 
2. Виявлено області, де за останні роки спостерігається збільшення постачання привізної води, їх можна розташувати в такий ряд за величною зазначеного показника: Запорізька > Дніпропетровська > Миколаївська > Одеська $>$ Донецька $>$ Львівська > Кіровоградська. Підтверджено, що за наявності відповідних умов доцільніше використовувати мобільні установки, встановлені в автомобільному транспорті, перевагою яких $є$ можливість забезпечення питною водою споживачів у необмеженій кількості протягом тривалого часу.

3. Уперше систематизовано привізні питні води в залежності від якості питної води та виду тари для транспортування споживачеві. Виявлено, що серед досліджених 129 питних вод фасованих та з пунктів розливу поліпшеної якості близько 31 \% виготовлялось насамперед після очищення для реалізації з пунктів розливу, у тому числі автоцистерн, або постачання споживачеві в тарі багаторазового використання. Виявлено 12 проблемних показників у водах після додаткової обробки водопровідних питних вод (8 - 3 поверхневих джерел) та 13 - 3 підземних джерел. Установлено, що до невідповідної якості питної води призводить відсутність професійного підбору водоочисного обладнання, зокрема порушення чинних нормативних вимог щодо проведення попередніх досліджень вихідної води, вибору раціональної схеми та технології водопідготовки, а також державного нагляду за якістю питної води тощо.

\section{References}

Averyn, G., Golubeva, L. (2002). Problemy ekologicheskogo monitoring rechnykh vodnykh obektov [Problems of ecological monitoring of river water bodies]. Donbas 2020: Science and technology - for production: collection of thesis of academic and practical conference. Donetsk, 19-23 (in Russian).

Bardov, V., Fedorenko, V. (2013). Osnovy ekologii [The Fundamentals of Ecology]. New book, Kyiv (in Ukrainian).

Chumak, Y., Zubko, M., Rodina, R. (2016). Gospodarsko-pitne vodopostachanie ta stan poverkhnevykh vodoym v Ukraini [Domestic and potable water supply, and the state of surface reservoirs in Ukraine]. Topical issues of hygiene and ecological safety of Ukraine: collection of thesis of academic and practical conference, Kyiv, 200-201 (in Ukrainian).

Fagurova, O. (2010). Pravovoe reguliuvanie zabezpechenia tsentralizovanym vodopostachaniem silskikh naselenykh punktiv [Legal regulation of centralized water supply in rural human settlements]. Legal Ukraine. Agrarian, land, and 1 environmental law, 2, 72-76 (in Ukrainian).

Fakhri, Y., Khaneghah, A., Hadiani, M., Keramati, H. (2017). Non-carcinogenic risk assessment induced by heavy metals content of the bottled water in Iran. Toxin Reviews, 36(4), 313-321.

Grazuleviciene, R., Kapustinskiene, V., Vencloviene, J., Buinauskiene, J., Nieuwenhuijsen, M. (2013). Risk of congenital anomalies in relation to the uptake of trihalomethane from drinking water during pregnancy. Occupational and Environmental Medicine, 70, 274-282.
Huzhnyak, M., Bidnenko, L., Yakymets, V. (2011). Viyskova gigena (zagalni pytania). [Military hygiene (general issues)]. UMMA, Kyiv (in Ukrainian).

Natsionalna dopovid (2009). Pro yakist pitnoi vody ta stan pitnogo vodopostachania v Ukraina u 2009 rotsi. [National report on potable water quality and the state of potable water supply in Ukraine in 2009. [Electronic variant]. Access mode: http://www.irbis-nbuv.gov.ua/cgibin/irbis64r_81/cgiirbis_64.exe?C21COM=2\&I21DBN=V FEIR\&P21DBN=VFEIR $\& Z 21$ ID $=\& I M A G E$ FILE DOW NLOAD $=1 \&$ Image_file_name $=$ DOC $\% 2$ FREP0000735.PDF (in Ukrainian).

Natsionalna dopovid (2014). Pro yakist pitnoi vody ta stan pitnogo vodopostachania v Ukraina u 2014 rotsi. [National report on potable water quality and the state of potable water supply in Ukraine in 2014]. [Electronic variant]. Access mode: http://www.minregion.gov.ua/wpcontent/uploads/2016/10/Natsionalna-dopovid-za-2014.pdf (in Ukrainian)

Natsionalna dopovid (2015). Pro yakist pitnoi vody ta stan pitnogo vodopostachania v Ukraina u 2015 rotsi. [National report on potable water quality and the state of potable water supply in Ukraine in 2015]. [Electronic variant]. Access mode: http://www.minregion.gov.ua/wpcontent/uploads/2016/10/Natsionalna-dopovid-za-2015.pdf (in Ukrainian).

Natsionalna dopovid (2016). Pro yakist pitnoi vody ta stan pitnogo vodopostachania v Ukraina u 2016 rotsi. [National report on potable water quality and the state of potable water supply in Ukraine in 2016]. [Electronic variant]. Access mode: http://www.minregion.gov.ua/wpcontent/uploads/2017/12/Proekt-Nats.-dop.-za-2016-rik.pdf (in Ukrainian).

Norman, R. E., Carpenter, D. O., Scott, J., Brune, M. N., Sly, P. D. (2013). Environmental exposures: an underrecognized contribution to noncommunicable diseases. Reviews on Environmental Health, 28(1), 59-65.

Prokopov, V. (2016). Pitna voda Ukraini: medico-ekologichni ta sanitarno-gigienechni aspekty [Potable water in Ukraine: medical environmental, and hygiene issues]. Medicine, Kyiv (in Ukrainian).

Smith, R., Nieuwenhuijsen, M., Wright, J., Raynor, P., Cocker, J., Jones, K. (2013). Validation of trichloroacetic acid exposure via drinking water during pregnancy using a urinary TCAA biomarker. Environmental Research, 126, $145-151$.

Stashuk, V., Stashuk, A. (2010). Doslidjenia stanu pitnogo vodopostachania u silskiy mistsevosti Ukrainy ta vyznachenia perspektyvnykh shliakhiv yogo vyrishenia [Research of the potable water supply in rural rural human settlements of Ukraine and determination of perspective ways for its improvement]. [Electronic source]. Access mode: https://vestnikconstruction.com.ua/images/pdf/62_2010/stashuk.pdf Ukrainian).

U.S. Environmental Protection Agency (EPA) (2011). «Planning for an Emergency Drinking Water Supply». Washington, D.C.: U.S. Environmental Protection Agency, Office of Water, EPA 600/R-11/054. [Electronic source]. Access mode: https://www.awwa.org/Portals/0/files/resources/water\%20kno wledge/rc\%20emergency\%20prep/Emergencywater.PDF. 